\title{
Bahan Ajar Matematika Berbasis Model Pembelajaran Tematik terhadap Kemampuan Berhitung Anak Usia Dini
}

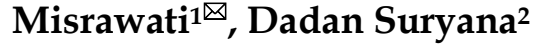 \\ Pendidikan Anak Usia Dini, Universitas Negeri Padang, Indonesia(1,2) \\ DOI: $\underline{10.31004 / o b s e s i . v 6 i 1.1249}$
}

\begin{abstract}
Abstrak
Bahan ajar merupakan bahan-bahan atau materi pembelajaran yang disusun secara sistematis yang digunakan guru dan siswa dalam proses pembelajaran di sekolah. Bahan ajar yang digunakan yaitu bahan ajar berupa buku paket yang peneliti gunakan di sekolah. Penelitian ini bertujuan untuk melihat bagaimana pengaruh bahan ajar matematika terhadap kemampuan berhitung anak di Taman Kanak-kanak Pertiwi Kabupaten Solok. Jenis penelitian ini yaitu menggunakan penelitian kuantitatif. Subjek dalam penelitian ini yaitu guru di Taman Kanak-kanak Pertiwi Kabupaten Solok. Teknik analisis data yang digunakan yaitu menggunakan aplikasi SPSS 22. Teknik pengumpulan data yaitu menggunakan angket yang sudah divalidasi oleh dosen. Hasil penelitian menunjukkan bahwa bahan ajar matematika berpengaruh secara langsung terhadap kemampuan matematika anak. Hal ini terlihat bahwa pada saat melakukan tanya jawab seputar matematika, anak terlihat aktif dalam menjawab berbagai pertanyaan yang dilakukan oleh guru. Selain itu, pada saat diskusi di dalam kelas terlihat anak-anak sangat antusias saat belajar menggunakan bahan ajar matematika.
\end{abstract}

Kata Kunci: Bahan Ajar, Pembelajaran Matematika, Anak Usia Dini

\begin{abstract}
Teaching materials are materials or learning materials that are systematically arranged that are used by teachers and students in the learning process at school. Teaching materials used are teaching materials in the form of textbooks that researchers use in schools. This study aims to see how the influence of mathematics teaching materials on children's numeracy skills in Kindergarten Pertiwi Solok Regency. This type of research is using quantitative research. The subjects in this study were teachers in Kindergarten Pertiwi, Solok Regency. The data analysis technique used was the SPSS 22 application. The data collection technique used a questionnaire that had been validated by the lecturer. The results showed that mathematics teaching materials had a direct effect on children's mathematical abilities. It can be seen that when doing questions and answers about mathematics, children are seen to be active in answering various questions asked by the teacher. In addition, during the discussion in the class, the children were seen to be very enthusiastic when learning to use mathematics teaching materials.
\end{abstract}

Keywords: Teaching Materials, Mathematics Learning, Early Childhood

Copyright (c) 2021 Misrawati, Dadan Suryana

$\triangle$ Corresponding author:

Email Address : misrawati471@gmail.com (Padang, Indonesia)

Received 6 April 2021, Accepted 20 April 2021, Published 4 May 2021 


\section{PENDAHULUAN}

Pendidikan anak usia dini (PAUD) ditujukan bagi anak prasekolah agar anak dapat mengembangkan potensinya sejak usia dini, yaitu dengan memberikan rangsangan pendidikan untuk membantu pertumbuhan dan perkembangan jasmani dan rohani anak. Pendidikan anak usia dini merupakan pendidikan yang sangat penting karena pendidikan anak usia dini adalah pendidikan dasar yang menjadi landasan untuk melanjutkan pendidikan ke jenjang yang lebih tinggi.

Pertumbuhan dan perkembangan anak yang optimal akan mempengaruhi kesiapan anak untuk menjalankan pendidikan berikutnya. Berdasarkan pendapat Suryana (2013) Lembaga Pendidikan anak usia dini dengan adanya Direktorat PNFI mengitegrasikan penyelenggaraan TPA (Taman Penitipan Anak), KB (Kelompok Bermain), TK (Taman kanakkanak) dan SPS (Satuan Paud Sejenis). Suryana (2014) Anak usia 4-6 tahun merupakan bagian dari anak usia dini yang berada pada rentangan usia lahir sampai 6 tahun. Pada usia ini secara terminologi disebut sebagai anak usia prasekolah. (Suryana, 2011) Anak usia dini memiliki lima aspek perkembangan, yaitu perkembangan nilai agama dan moral, kognitif, bahasa, fisik motorik, dan sosial-emosional. Aspek-aspek perkembangan tersebut harus mendapatkan stimulasi optimal dari lingkungan sekitar. Stimulasi pembelajaran yang dilakukan di sekolah merupakan salah satu stimulus yang dapat mengembangkan aspek-aspek tersebut di atas.

Pertumbuhan dan perkembangan anak yang optimal akan mempengaruhi kesiapan anak untuk menjalankan pendidikan berikutnya. Hal ini sejalan dengan pendapat (Suryana, 2013) mendefinisikan anak usia dini adalah sosok individu sebagai makhluk sosiokultural yang sedang mengalami proses perkembangan yang sangat fundamental bagi kehidupan selanjutnya dan memiliki beberapa karakteristik. Selain itu, (Suryana, 2016) juga mendefinisikan pendidikan anak usia dini adalah upaya pembinaan kepada anak sejak lahir hingga usia enam tahun yang dilakukan dengan memberikan rangsangan pendidikan untuk membantu pertumbuhan dan perkembangan jasmani dan rohani agar anak memilki kesiapan untuk memasuki pendidikan lebih lanjut.

Anak usia dini berada pada masa keemasan (golden age) sehingga stimulasi yang optimal akan mengoptimalkan tumbuh kembang anak. Seluruh aspek perkembangan anak saling mempengaruhi dengan aspek lainnya. Oleh karena itu, Pendidikan TK sangat berperan sebagai wahana dalam menjamin dan mengoptimalkan tumbuh kembang anak. Penggunaan media dan bahan ajar sangat menentukan keberhasilan proses belajar mengajar. Berbagai bentuk media dan bahan ajar yang digunakan harus sesuai kebutuhan dan tahapan perkembangan anak.

Media pembelajaran sebagai penyampaian materi dengan mengutamakan prinsip belajar anak yaitu bermain sambil belajar dan belajar seraya bermain. Media tersebut bisa berupa alat permainan, bahan ajar, majalah dan lain-lain. Bahan ajar merupakan materi pembelajaran yang dirancang secara sistematis dengan menyediakan sejumlah informasi pengetahuan, pengalaman, dan keterampilan dalam proses belajar mengajar.

Bahan ajar pada pembelajaran di jenjang paud yang dapat dipadukan dengan pendekatan tematik anak usia dini atau terintegrasi dengan tema. Oleh karena itu bahan ajar untuk anak usia dini disusun dengan menggunakan pendekatan tematik atau terintegrasi dengan tema. Penyusunan tersebut bertujuan agar pembelajaran dapat terlaksana sesuai dengan kurikulum menggunakan bahan ajar. Tematik merupakan pembelajaran yang menjadikan anak aktif dengan pembelajaran yang utuh dan menyeluruh sehingga anak mendapatkan pengetahuan dan pengalaman yang bermakna.

Pembelajaran tematik merupakan suatu bentuk pembelajaran yang mengaitkan pada satu tema untuk beberapa bidang pengembangan anak. Tematik merupakan model pembelajaran yang menggunakan tema dengan mengaitkan beberapa pengembangan pada anak usia dini sehingga dapat memberikan pengalaman bermakna kepada anak. Penggunaan tema dimaksudkan agar anak mendapatkan pengetahuan secara utuh dan mendalam tentang suatu hal. Pembelajaran dengan bahan ajar tematik dapat memberikan anak berbagai 
pembelajaran yang dirangkum atau diintegrasikan pada satu tema. Salah satu kemampuan yang sangat dibutuhkan pada saat ini adalah matematika.

Pembelajaran matematika merupakan pembelajaran yang berhubungan dengan bilangan dan analisis. Bagi anak usia dini matematika adalah pemahaman tentang angka, pengukuran dan pengklasifikasian. Matematika sangat dibutuhkan dalam menstimulasi kemampuan berpikir dan daya ingat anak serta mempengaruhi perkembangan aspek lainnya. Anak dituntut untuk dapat menghadapi tantangan kehidupan yang global dan dapat memecahkan masalah yang ada pada kehidupannya. Oleh karena itu, pembelajaran matematika sejak usia dini bermanfaat dalam menyiapkan anak menyelesaikan permasalahan dalam kehidupan sehari-hari. Hasil penelitian (Mirawati, 2017) pembelajaran matematika yang dilaksanakan di berbagai lembaga PAUD terkadang tidak sesuai dengan tahapan perkembangan anak dan cenderung terjadi kekeliruan dalam pelaksanaannya.

Sejalan dengan hasil observasi dan wawancara di Taman Kanak-kanak Pertiwi Koto Gadang Kabupaten Solok ditemukan bahwa sekolah belum memiliki modul pembelajaran mengacu pada kurikulum 2013 seperti RPPM dan RPPH. Pembelajaran seringkali belum terencana dengan baik termasuk pembelajaran matematika. Berdasarkan uraian diatas penulis tertarik untuk melakukan penelitian tentang Pengaruh Bahan Ajar Matematika Terhadap Kemampuan Berhitung Anak Usia Dini Di Taman Kanak-Kanak Pertiwi Koto Gadang Kabupaten Solok.

\section{METODOLOGI}

Penelitian dengan judul Pengaruh Bahan Ajar Matematika Terhadap Kemampuan Berhitung Anak Usia Dini Di Taman Kanak-Kanak Pertiwi Koto Gadang Kabupaten Solok. Menggunakan jenis penelitian menggunakan metode kuantitatif. Menurut Sugiyono (2016) metode kuantitatif yaitu metode yang berdasar filsafat positivisme bertujuan menggambarkan dan menguji hipotesis yang dibuat peneliti. Penelitian kuantitatif adalah aktivitas pengumpulan dan analisis data yang bersifat angka atau numerik. Dimana proses ini bisa dipakai untuk memperoleh pola, prediksi, rata-rata, uji keterkaitan sebab akibat dan generalisasi hasil.

Instrumen yang digunakan diambil dari teori-teori. Sebelum peneliti terjun langsung ke lapangan, peneliti terlebih dahulu melakukan validasi dengan beberapa ahli materi maupun ahli media. Bahan ajar yang peneliti gunakan yaitu bahan ajar yang sudah ada di sekolah yang dibuat oleh guru-guru kelas di tempat peneliti mengajar. Teknik analisis data yang digunakan yaitu menggunakan aplikasi SPSS 22. Teknik pengumpulan data yaitu menggunakan angket yang sudah divalidasi oleh dosen.

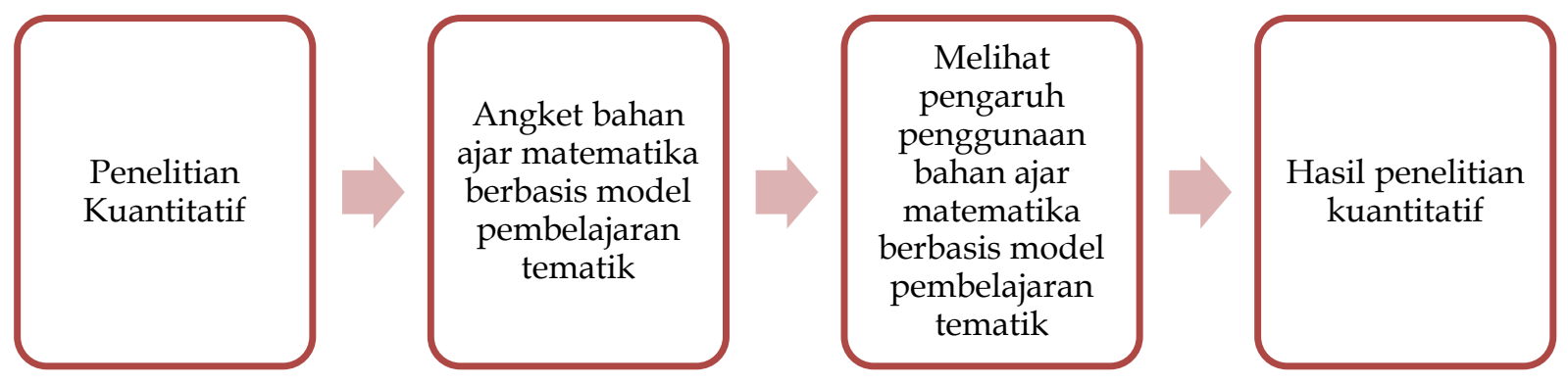

Gambar 1. Bagan alur penelitian

\section{HASIL DAN PEMBAHASAN}

Berdasarkan hasil penelitian terdahulu yang dilakukan oleh (Semiawan, 2018) ditemukan bahwa penelitian yang dilakukan bertujuan untuk meningkatkan kemampuan penjumlahan melalui media pembelajaran matematika pada anak kelompok A RA Ma'arif 1 Kota Metro. Permasalahan yang digunakan berupa soal cerita dengan menggunakan 
Bahan Ajar Matematika Berbasis Model Pembelajaran Tematik terhadap Kemampuan Berhitung Anak Usia Dini DOI: 10.31004/obsesi.v6i1.1249

benda-benda yang sering ditemui anak. Selanjutnya berdasarkan hasil penelitian (Rohmah, 2016) ditemukan bahwa tujuan penelitian yang dilakukannya yaitu menganalisis hasil belajar kemampuan matematika antara kelompok eksperimen dan kelompok kontrol, menganalisis keefektifan model pembelajaran kooperatif melalui media dadu dalam pengembangan kemampuan matematika bagi anak usia dini; dan memaparkan respons anak-anak terhadap model pembelajaran kooperatif melalui media dadu dalam pengembangan kemampuan matematika bagi anak usia dini.

Penelitian yang peneliti lakukan terdapat inovasi dari segi media yang digunakan yaitu berupa bahan ajar matematika berbasis model pembelajaran tematik terhadap kemampuan berhitung anak usia dini. Berikut peneliti uraikan tahapan penelitian yang dilakukan.

Pada tahap awal penelitian, peneliti melakukan uji validitas. Berdasarkan hasil uji validitas dapat disimpulkan semua item bahan ajar matematika adalah valid dimana nilai correlated item total correlation $>0,334$. Sementara itu Berdasarkan hasil uji validitas dapat disimpulkan semua item berhitung adalah valid dimana nilai correlated item total correlation $>$ 0,334

Setelah melakukan uji validitas, selanjutnya peneliti melakukan uji reliabilitas. Uji relibilitas bertujuan untuk menilai sejauh mana jawaban dari responden dapat memberikan hasil yang relatif berbeda (konsisten) bila dilakukan pengulangan pengukuran terhadap subjek yang sama. Instrumen Reliabilitas (kehandalan) berarti instrumen yang digunakan beberapa kali untuk mengukur objek yang sama, instrumen yang telah valid kemudian dilakukan uji reliabilitas menggunakan rumus Cronbachs Apha dengan bantuan SPSS versi 22 Jika $r$ alpha positif dan besar dari $r$ tabel $(0,334)$ berarti keseluruhan butir instrumen tersebut reliable. Tabel 1. Adalah hasil pengujian realibilitas masing-masing variabel penelitian.

Tabel 1. Uji Reliabilitas

\begin{tabular}{|c|c|c|}
\hline No & cronbachs apha & Keterangan \\
\hline 1 & 0,701 & Reliabel \\
2 & 0,656 & Reliabel \\
3 & 0,684 & Reliabel \\
4 & 0,603 & Reliabel \\
5 & 0,632 & Reliabel \\
6 & 0,783 & Reliabel \\
\hline
\end{tabular}

Berdasarkan tabel 1 dapat disimpulkan bahwa semua item pertanyaan realiabel. Semua variabel reliabel disebabkan karena hasil correlated total item corelation besar dari 0,334 (untuk $\mathrm{n}=35 \mathrm{r}$ table $=0,334$ )

Setelah peneliti melakukan uji reliabilitas, selanjutnya peneliti melakukan uji normalitas. Uji Normalitas dilakukan dengan maksud memeriksa apakah terdistribusi normal atau tidak. Menurut (Ghozali, 2016) pedoman yang dipakai dalam uji normalitas ini adalah menggunakan uji kolmogov Smirnov yaitu: Jika nilai sig atau signifikansi atau nilai propanilitas (p) <0,05 (taraf kepercayaan 95\%), distribusi adalah tidak normal. Jika nilai sig tau signifikansi atau nilai probabilitas (p) > 0,05 (taraf kepercayan 95\%), distribusi adalah normal. Adapun hasil pengolahan data untuk uji normalitas dapat dilihat pada Tabel berikut ini

Berdasarkan tabel 2, hasil olahan data diatas menghasilkan Nilai Signifikan yakni 0,484 artinya 0,05, dengan demikian dapat disimpulkan data berdistribusi Normal. Salah satu syarat untuk memakai analisis dengan menggunakan regresi linear berganda terlebih dahulu dilakukan uji multikolinearitas yaitu hubungan sesama variabel bebas. Pengujian multikolinearitas dilakukan untuk mengetahui apakah antar variabel bebas memiliki 
hubungan satu sama lainnya. Yang dimaksud dengan uji multikolinearitas adalah uji yang dilakukan untuk mengetahui apakah terdapat kasus multikolinearitas antara sesama variabel bebas. Jika terdapat multikolinearitas maka, salah satu dari variabel tersebut harus dieleminir atau dikeluarkan dari persamaan. Hasil uji multikolineritas dapat dilihat pada tabel 3.

Tabel 2. Uji Normalitas

\begin{tabular}{lcc}
\hline & & Keterangan \\
\hline Kolmogov-Smirnov Z & 0,838 & Normal \\
Asymp. Sig. (2-tailed) & 0,484 & Normal \\
\hline
\end{tabular}

Tabel 3. Hasil Uji Multikolinieritas

\begin{tabular}{|c|c|c|}
\hline \multicolumn{3}{|c|}{ Collinearity Statistics } \\
\hline Tolerance & VIF & Keterangan \\
\hline 0,778 & 1.269 & Tidak Multikoinearitas \\
\hline 0,647 & 1.546 & Tidak Multikoinearitas \\
\hline 0,638 & 1.567 & Tidak Multikoinearitas \\
\hline 0,625 & 1.601 & Tidak Multikoinearitas \\
\hline 0,683 & 1.463 & Tidak Multikoinearitas \\
\hline
\end{tabular}

Berdasarkan hasil olahan data untuk menguji multikolinearitas sebagaimanana terlihat pada tabel 3 diatas diketahui bahwa nilai tolerance dari Collinearity Statistics mendekati i (satu) dan nilai VIF (Variance Inflation Factor) untuk semua variabel bebas di bawah 10 (sepuluh). Hal ini menunjukkan bahwa tidak hubungan yang berarti yang antara sesama variabel bebas. Oleh karena itu dapat disimpulkan bahwa data hasil penelitian ini tidak mengalami kasus multikolinearitas sehingga pengolahan data dengan regresi linear berganda dapat dilakukan karena tidak terdapat kasus multikolinearitas antara sesama variabel bebas.

Tabel 5. Hasil Uji Autokorelasi Model Summary

\begin{tabular}{|c|c|c|c|c|c|c|c|c|c|c|}
\hline \multirow[b]{2}{*}{ Model } & \multirow[b]{2}{*}{$\mathrm{R}$} & \multirow[b]{2}{*}{ R Square } & \multirow[b]{2}{*}{$\begin{array}{l}\text { Adjusted } \\
\text { R Square }\end{array}$} & \multirow[b]{2}{*}{$\begin{array}{l}\text { Std. Error of } \\
\text { the Estimate }\end{array}$} & \multicolumn{5}{|c|}{ Change Statistics } & \multirow[b]{2}{*}{$\begin{array}{l}\text { Durbin- } \\
\text { Watson }\end{array}$} \\
\hline & & & & & $\begin{array}{c}\text { R Square } \\
\text { Change }\end{array}$ & F Change & df1 & df2 & $\begin{array}{l}\text { Sig. F } \\
\text { Change }\end{array}$ & \\
\hline 1 & $.568^{\mathrm{a}}$ & .323 & .285 & .98509 & .323 & 8.578 & 5 & 90 & .000 & .719 \\
\hline
\end{tabular}

Berdasarkan tabel diatas dapat disimpulkan bahwa Regresi dikatakan memenuhi persyaratan autokorelasi jika nilai $\mathrm{DW}<10$. Hasil olahan didapat nilai $\mathrm{DW}=0,719$, Dengan demikian model regresi sudah memenuhi persyaratan asumsi klasik dimana tidak terjadi autokorelasi atau memenuhi persyaratan autokorelasi.

Setelah melakukan uji autokorelasi, selanjutnya peneliti melakukan Uji F. Uji F digunakan untuk melihat pengaruh secara keseluruhan dari variabel independen dengan variabel dependen. Dengan bantuan program SPSS V.22 diketahui nilai F hitung pada tabel 6.

Berdasarkan uji $\mathrm{F}$ diketahui bahwa nilai $\mathrm{F}$ hitung 128.958 dengan nilai signifikansi sebesar 0,000 $(p<0,05)$. Hal ini berarti secara bersama-sama variabel bahan ajar matematika berpengaruh terhadap kemampuan berhitung anak. Setelah peneliti melakukan uji F, selanjutnya peneliti melakukan Uji R Square. Hasil penelitian menggunakan R Square seperti yang terlihat pada tabel 7.

Hasil Nilai $\mathrm{R}^{2}$ (R-Square) digunakan untuk mengukur seberapa besar proporsi variasi dari variabel independen secara bersama-sama dalam mempengaruhi variabel dependen. Berdasarkan hasil pengolahan data diketahui bahwa nilai uji $\mathrm{R}^{2}$ (Adjusted $R$-Square) adalah sebesar 0,323 hal ini berarti besarnya pengaruh bahan ajar matematika berpengaruh terhadap 
Bahan Ajar Matematika Berbasis Model Pembelajaran Tematik terhadap Kemampuan Berhitung Anak Usia Dini DOI: 10.31004/obsesi.v6i1.1249

perkembangan berhitung anak sebesar 32,3\% sisanya dijelaskan oleh variabel lain yang tidak masuk ke dalam model penelitian.

Tabel 6. Hasil Uji F

\begin{tabular}{|c|c|c|c|c|c|c|}
\hline \multicolumn{7}{|c|}{ ANOVA $^{b}$} \\
\hline \multicolumn{2}{|c|}{ Model } & $\begin{array}{l}\text { Sum of } \\
\text { Squares }\end{array}$ & Df & $\begin{array}{l}\text { Mean } \\
\text { Square }\end{array}$ & F & Sig. \\
\hline 1 & Regression & 41.622 & 5 & 8.324 & 8.578 & $.000^{\mathrm{a}}$ \\
\hline & Residual & 87.337 & 90 & .970 & & \\
\hline & Total & 128.958 & 95 & & & \\
\hline
\end{tabular}

Tabel. 7. Uji R Square

\begin{tabular}{|c|c|c|c|c|c|c|c|c|c|c|}
\hline \multicolumn{11}{|c|}{ Model Summaryb } \\
\hline \multirow[b]{2}{*}{ Model } & \multirow[b]{2}{*}{$\mathrm{R}$} & \multirow[b]{2}{*}{ R Square } & \multirow[b]{2}{*}{$\begin{array}{c}\text { Adjusted R } \\
\text { Square }\end{array}$} & \multirow{2}{*}{$\begin{array}{l}\text { Std. Error } \\
\text { of the } \\
\text { Estimate }\end{array}$} & \multicolumn{5}{|c|}{ Change Statistics } & \multirow[b]{2}{*}{$\begin{array}{l}\text { Durbin- } \\
\text { Watson }\end{array}$} \\
\hline & & & & & $\begin{array}{c}\text { R Square } \\
\text { Change }\end{array}$ & F Change & df1 & df2 & \begin{tabular}{|c|} 
Sig. F \\
Change
\end{tabular} & \\
\hline 1 & $.568^{a}$ & .323 & .285 & .98509 & .323 & 8.578 & 5 & 90 & .000 & .719 \\
\hline
\end{tabular}

Bahan ajar merupakan salah satu perangkat pembelajaran. Menurut (Nasrul, 2018) Bahan ajar merupakan bahan-bahan atau materi pembelajaran yang disusun secara sistematis yang digunakan guru dan siswa dalam proses pembelajaran di sekolah. Bahan ajar merupakan salah satu sumber belajar, yakni segala sesuatu yang memudahkan peserta didik memperoleh sejumlah informasi pengetahuan, pengalaman, dan keterampilan dalam proses belajar mengajar. Menurut Marta \& Harijal (2018) Bahan ajar adalah segala sesuatu atau daya yang dapat dimanfaatkan oleh guru, baik secara terpisah maupun dalam bentuk gabungan, untuk kepentingan belajar mengajar dengan tujuan meningkatkan efektivitas dan efisiensi tujuan pembelajaran. Penyusunan bahan ajar sangat menentukan tercapainya tujuan pembelajaran. Menurut (Purnomo \& Wulandari, 2019) Bahan ajar merupakan satu kesatuan dari berbagai komponen yang ada di dalam penyusunan materi pembelajaran, sehingga perlunya sebuah susunan bahan ajar yang sesuai dengan standar yang jelas.

Menurut Muri et al. (2018) kegunaan bahan ajar sebagai media pendidikan sebagai berikut: (a) menimbulkan kegairahan belajar; (b) memungkinkan interaksi yang lebih langsung antara anak didik dengan lingkungan dan kenyataan; (c) memungkinkan anak didik belajar sendiri sendiri menurut kemampuan dan minatnya. Menurut (Kenedi et al., 2018) pengunaan bahan ajar menjadi salah satu solusi untuk meningkatkan proses pembelajaran. Perancangan bahan ajar yang sesuai dengan kebutuhan dan karakteristik anak akan menciptakan pembelajaran yang efektif dan kondusif.

Bahan ajar dikembangkan dan disusun sesuai dengan tuntutan kurikulum dengan mempertimbangkan kebutuhan peserta didik, yakni bahan ajar yang sesuai dengan karakteristik dan lingkungan sosial peserta didik. Pembelajaran matematika merupakan pembelajaran yang berhubungan dengan angka dan analisis. Menurut Gardner (2011) ahli matematika menggaris bawahi pentingnya angka sebagai dasar untuk pengembangan matematika. Montessori berpendapat bahwa pada usia 3-5 tahun, anak-anak sudah dapat dikenalkan pada kegiatan menulis, membaca, dan berhitung (Montessori, 2008).

Bagi anak usia dini matematika adalah pemahaman tentang angka. Matematika sangat dibutuhkan untuk menstimulasi kemampuan berpikir anak dan juga mampu melatih daya ingat anak serta mengoptimalkan kemampuan logika matematika atau kemampuan lainnya yang akan berdampak pada pendidikan tahap selanjutnya Susanti et al. (2020). Matematika sebagai salah satu ilmu dasar, baik aspek terapan maupun aspek penalarannya memiliki peranan penting dalam upaya penguasaan ilmu dan teknologi menghadapi tantangan 
kehidupan di zaman global (Nisa' \& Karim, 2017). Anak dituntut untuk dapat menghadapi tantangan kehidupan yang global dan dapat memecahkan masalah yang ada pada kehidupannya.

Sejalan dengan pendapat (Handayani, 2018) Matematika merupakan ilmu pokok yang harus dikuasai karena ilmu dan pengetahuan yang dibutuhkan dalam kehidupan keseharian. Menurut (Setiawan \& Aprianti, 2018) Kecerdasan logis matematis AUD dikembangkan melalui: mengenal beberapa bilangan, beberapa pola, perhitungan, pengukuran, geometri, dan pengklasifikasian. Pembelajaran matematika pada anak usia dini adalah belajar terkait kegiatan sehari-hari yang bertujuan menghubungkan pengetahuan matematika informal anak-anak dengan konsep matematika yang lebih formal. Menurut (Wardhani, 2017) Materi dan konsep matematika yang diajarkan harus disesuaikan dengan kemampuan dan tahap berfikir anak yang bersangkutan sehingga membangun rasa ingin tahu anak secara alami tentang bentuk, ukuran, jumlah, konsep-konsep dasar lain dalam matematika. Menurut Mirawati (2017) Konsep pembelajaran matematika bagi anak usia dini seharusnya disesuaikan dengan kebutuhan dan tahapan perkembangan anak, termasuk pemilihan pendekatan pembelajaran yang akan dilaksanakan.

Anak usia dini merupakan individu yang berada pada masa perkembangan dan pertumbuhan yang pesat. Menurut Sujiono (2011) Anak usia dini adalah sosok individu yang sedang menjalani suatu proses perkembangan dengan pesat dan fundamental bagi kehidupan selanjutnya. Menurut Khairi (2018) Karakteristik anak usia dini a) Unik; b) Egosentris; c) Aktif dan energik; d) Rasa ingin tahu yang kuat dan antusias terhadap banyak hal; e) Eksploratif dan berjiwa petualang; f) Spontan; g) Senang dan kaya dalam fantasi; h) Masih mudah frustasi; i) Masih kurang pertimbangan dalam melakukan sesuatu; j) Daya perhatian yang pendek; k) Bergairah untuk belajar dan banyak belajar dari pengalaman; l) Semakin menunjukkan minat terhadap teman. Hal ini beriringan dengan bertambahnya usia dan perkembangan yang dimiliki oleh anak.

Menurut Sapriani (2019) Pendidikan Anak Usia Dini (PAUD) merupakan satuan pendidikan yang sangat fundamental dalam memberikan kerangka dasar terbentuk dan berkembangnya sikap, dasar-dasar pengetahuan dan keterampilan. PAUD merupaka satuan lembaga pendidikan yang menitik beratkan kepada tumbuh kembang anak. Pendidikan anak usia dini adalah suatu upaya pembinaan yang ditujukan kepada anak sejak lahir hingga usia enam tahun yang dilakukan melalui pemberian stimulasi pendidikan untuk membantu pertumbuhan dan perkembangan jasmani dan rohani agar anak memiliki kesiapan dalam memasuki pendidikan lebih lanjut. Menurut Trianto (2011) PAUD bertujuan membimbing dan mengembangkan potensi setiap anak agar dapat berkembang potensi setiap anak agar dapat berkembang secara optimal sesuai tipe kecerdasannya. Oleh karena itu pembimbingan dan pengembangan potensi anak secara optimal dalam pembelajaran sebagai tujuan dari penyelenggaraan PAUD.

\section{SIMPULAN}

Berdasarkan hasil analisis data menggunakan aplikasi SPSS terdapat besar proporsi variasi dari variabel independen secara bersama-sama dalam mempengaruhi variabel dependen. Berdasarkan hasil pengolahan data diketahui bahwa nilai uji $\mathrm{R}^{2}$ (Adjusted $R$-Square) adalah sebesar 0,323 hal ini berarti besarnya pengaruh bahan ajar matematika berpengaruh terhadap perkembangan berhitung anak sebesar 32,3\% sisanya dijelaskan oleh variabel lain yang tidak masuk ke dalam model penelitian. Penyusunan bahan ajar sangat menentukan tercapainya tujuan pembelajaran. Bagi anak usia dini matematika adalah pemahaman tentang angka.

\section{UCAPAN TERIMA KASIH}

Penulis mengucapkan banyak terima kasih kepada penulis buku maupun penulis artikel yang penulis kutip. Kutipan ini sangat bermanfaat bagi penulis untuk mendapatkan 
Bahan Ajar Matematika Berbasis Model Pembelajaran Tematik terhadap Kemampuan Berhitung Anak Usia Dini DOI: 10.31004/obsesi.v6i1.1249

kajian literatus dalam penulisan artikel ini. Selain itu penulis juga mengucapkan banyak terima kasih kepada pembimbing yang sudah memberikan kritik dan saran dalam penulisan artikel ini. Selanjutnya peneliti juga mengucapkan terima kasih kepada guru-guru di Taman Kanak-kanak Pertiwi Taman Kanak-Kanak Pertiwi Koto Gadang Kabupaten Solok.Selain itu peneliti mengucapkan terima kasih kepada teman-teman yang sudah banyak membantu dalam memberikan semangat kepada peneliti. Terima kasih yang sebesar-besarnya bagi keluarga yang sudah memberikan banyak dukungan kepada peneliti.

\section{DAFTAR PUSTAKA}

Handayani, O. D. (2018). Pembelajaran Matematika Permulaan melalui Kewirausahaan pada Aktivitas Bercocok Tanam pada Anak Usia Dini. Jurnal Penelitian Dalam Bidang Pendidikan Anak Usia Dini, 7, 71-84. https:// doi.org/10.26877/paudia.v7i2.3270

Kenedi, A. K., Helsa, Y., \& Hendri, S. (2018). Pengembangan Bahan Ajar Matematika Berbasis Alquran Di Sekolah Dasar. Jurnal Inovasi Pendidikan Dan Pembelajaran Sekolah Dasar, 2, 29-36. https:// doi.org/10.24036/jippsd.v2i1.100034

Khairi, H. (2018). Karakteristik Perkembangan Anak Usia Dini dari 0-6 Tahun. Jurnal Warna, 2(2), 15-28. ejournal.iaiig.ac.id > index.php > warna > article > download

Marta, E., \& H. (2018). Pengembangan Bahan Ajar Menggunakan Model Problem Based Learning di Kelas V Sekolah Dasar. Jurnal Pendidikan Rokania, 3, 347-356.

Mirawati. (2017). Matematika Kreatif: Pembelajaran Matematika bagi Anak Usia Dini melalui Kegiatan yang Menyenangkan dan Bermakna. Pedagogi. Jurnal Anak Usia Dini Dan Pendidikan Anak Usia Dini, 3, 1-8.

Montessori, M. (2008). The Absorbent Mind (Pikiran yang Mudah Menyerap). Pustaka pelajar. https://doi.org/10.36733/jsp.v9i2.393

Muri, L., Marzuki, \& R. (2018). Pengembangan Bahan Ajar Ilmu Pengetahuan Alam Project based learning model. Jurnal Pendidikan Dan Pembelajaran Khatulistiwa, 7, 1-9.

Nasrul, S. (2018). Pengembangan Bahan Ajar Tematik Terpadu Berbasis Model Problem Based Learning di Kelas IV Sekolah Dasar. Jurnal Inovasi Pendidikan Dan Pembelajaran Sekolah Dasar, 2, 81-92. https://doi.org/10.24036/jippsd.v2i1.100491

Nisa', F. T., \& Karim, M. B. (2017). Profil Kemampuan Matematika Anak Usia Dini melalui Learning to Think DIfferent. Jurnal PG-PAUD Trunojoyo, 4, 143-152. https://doi.org/10.21107/jpgpaud.v4i2.3576

Purnomo, H., \& Wulandari, I. (2019). Pengembangan Bahan Ajar Evaluasi Pembelajaran untuk Pendidikan Guru Sekolah Dasar Universitas Kuningan. Jurnal Pendidikan Dan Pengajaran, 3, 1204-1215. https:// doi.org/10.33578/pjr.v3i6.7878

Sapriani, R. (2019). Profesionalisme Guru PAUD Melati Terpadu dalam Meningkatkan Mutu Pendidikan pada Era Revolusi Industri 4.0. Prosiding Seminar Nasional Program Pascasarjana Universitad PGRI Palembang, 741-754.

Setiawan, W., \& Aprianti, E. (2018). Peningkatan Kecerdasan Logika Matematika melalui Biblioterapi Anak Usia Dini Kelompok A di Kober Warna Plus. Jurnal Ceria, 1, 7-15. https://doi.org/10.22460/ceria.v1i4.p7-15

Sugiyono. (2016). Metode Penelitian Kuantitatif, Kualitatif dan R\&D. alfabeta.

Sujiono, Y. N. (2011). Konsep Dasar Pendidikan Anak Usia Dini. PT Indeks Macanan Jaya Cemerlang.

Suryana, D. (2013). Pendidikan Anak Usia Dini (teori dan praktik pembelajaran).

Suryana, D. (2016). Stimulasi dan Aspek Perkembangan Anak (Jakata). Kencana Prenada Media Group.

Suryana, D. (2011). Efektivitas Outbound dalam Mengembangkan Kepercayaan Diri pada Anak Taman Kanak-kanak PDadan Suryana. (2011). Efektivitas Outbound dalam Mengembangkan Kepercayaan Diri pada Anak Taman Kanak-kanak Pertiwi VI Padang. Jurusan Pendidikan Guru Pendidikan Anak Usia Dini. 
Suryana,D. (2014). Kurikulum Pendidikan Anak Usia Dini Berbasis Perkembangan Anak. Pesona Dasar Vol 1 No 3 April 2014

Susanti, S., Rachmawati, Y., \& Gustiana, A. D. (2020). Penerapan Model Contextual Teaching and Learning (CTL) untuk Meningkatkan Kemampuan Pengukuran dalam Pembelajaran Matematika Anak Usia Dini. Edukids. Edukids: Jurnal Pertumbuhan, Perkembangan, Dan Pendidikan Anak Usia Dini, 17, 11-18. https:// doi.org/10.17509/edukid.v17i1.22508

Trianto. (2011). Mengembangkan Model Pemelajatan Tematik. Prestasi Pustaka.

Wardhani, D. K. (2017). Peran Guru dalam Menerapkan Pembelajaran Matematika yang Menyenangkan bagi Anak Usia Dini. Jurnal Paud Agapedia, 1, 153-159. https://doi.org/10.17509/jpa.v1i2.9355 